\title{
Study on Social Development of Europe after World War II
}

\author{
Yanping Liu \\ School of Marxism, Changchun University of Science and Technology \\ Changchun 130022, China \\ E-mail: lyp@cust.edu.cn
}

\begin{abstract}
After World War II, Europe, especially western Europe and northern Europe, gradually stepped onto a path of social development that was different from America. Quite a lot of socialistic new factors came into being in the production relations, class relations, income distribution and superstructure, etc, in these countries, so that the capitalism in Europe presented obvious staggered qualitative change, which manifested clear-cut historical transitivity and further deeply reflected that the contemporary capitalism represented by Europe and America presented a double development trend. The social development trend in the almost five decades in Europe also further predicts that it is quietly possible that Europe may step towards another peaceful realization path of transitional socialism that is distinguished from the violent revolution.
\end{abstract}

Keywords: Europe, Social development, Socialism, Peaceful transition

We often make a partition between eastern countries and western countries in human civilization. The so-called western civilization mainly refers to civilization of America, Western Europe, Canada, Australia and New Zealand, etc, and they have the common characteristics that they implement market economy in economics, carry out democratic and republic system in politics and are deeply influenced by Christian in culture. Since these western countries are mainly concentrated in European and American areas, for a long time, Europe and America has become the byword of western countries. In the past, people often regarded Europe as a unified whole corresponding with eastern civilization. As a matter of fact, it can be discovered from the development trend of European countries after the Second World War, especially in the recent fifty years, the path of social development in Europe is greatly distinguished from that of America although they are both western capitalism countries.

\section{Path of social development in Europe after the Second World War}

Europe is the place of origin of capitalism civilization. Afterwards, all capitalism civilizations continuously established by America, without exception, were influenced by European capitalism civilization. However, in the recent five decades, the social development trend of Europe, especially Western European and Northern European countries, is quite different from that of America. If we say that the trend of continuous development of former system of capitalism is more obvious in America, then the trend of gradual growth of new social factors of socialism stands more out in America. For instance, in terms of production relations, America has always been adhering to the basic principle of sacred and inviolable private ownership system, in which the single private ownership mode takes up a leading position, whereas state-owned economy is rare and precious. By contrast, state-owned economy in Europe was greatly developed after the Second World wear and corporation capital ownership system and economy of stakeholders were rapidly developed. In terms of social economic operation, America is deeply influenced by neoliberalism, so it advocates cutting down on national intervention, whittling down public expenses, allowing for unrestrained freedom and giving more play to the role of market mechanism. By contrast, Europe is more inclined to accepting Keynesianism and advocates national intervention and regulation. In terms of income distribution, the gap between the rich and the poor in America is still being enlarged and polarization continues to be deepened, whereas Europe diminishes the gap between the rich and the poor by means of the policy of equalization of redistribution of income and carrying out the social welfare system of "from the cradle to the grave", and quite a large number of European countries eliminate polarization to a certain extent. In terms of external relations, America still implements everywhere the system of hegemonism, whereas Europe advocates resolving a contradiction with a peaceful negotiation method most of the time in international relations. Actually, in recent years, America has also discovered that it has walked towards a social development path different from Europe. American senior Councillor Robert Kagan ever pointed out, "In fact, Europeans and Americans do not own common world outlook any more". "Europeans believe, Europe itself has entered human paradise at a post historical period", whereas "Americans are still trapped deeply in their former history and cannot save themselves". (Note 1) 


\section{New social factors of socialism stand out in many countries in Europe.}

The development path of Europe, especially Western Europe and Northern Europe, not only reflects the social development trend that is distinguished from America, but also deeply proves that Europe has had quite a lot of socialism new social factors that cannot be ignored, which have stood out in all aspects and which are manifested as below:

In terms of production relations, although Europe is still based on private ownership system, the state-owned economy, cooperative economy, employee stock ownership plan and economy of stakeholders that were rapidly developed after the Second World War also indicate that the form of capitalism private ownership system in Europe also has changed locally. Private appropriation of the means of production by capitalists is the essential feature of capitalism and is also the core economic foundation of capitalism. However, after the Second World War, the tide of nationalization appears several times in Europe. For example, three times of the tide of nationalization appeared in France after the Second World War, and the tide of nationalization appeared twice in Britain. Although Italy, Germany and Austria did not conduct obvious nationalized movements after the Second World War, they also developed state-owned economy in succession in different forms and made state-owned economy become stably the important component of the entire state-owned economy. In addition to state-owned economy, Europe also has a lot of patterns of cooperative economy. Cooperative economy refers to the economic patterns that the laboring masses in capitalism society establish in order to improve production conditions and living conditions, obtain and maintain their own interests according to the principle of being freewill, mutual benefit, equal and democratic. Cooperative economy has had a long history in Europe, was developed on a large scale after the Second World War and so far has almost become the major economic situation in European agricultural production and operation. Rapid development of state-owned economy and cooperative economy means that capitalism in Europe is going through a transfer to social and economic organization of the mixed economic type or social capitalism, and "is a form of transition from capitalism production means to joint production means." (Note 2) Besides, the Employee Stock Ownership Plan (ESOP) that was rapidly developed in Europe after the Second World War has not only greatly pushed socialization of stock rights in European enterprises, but that "the more it is expanded and the more it invades into a new production section, the more it will eliminate private industries." The property it generates will be "property of producers who joint together, namely, direct social property." (Note 3)

In terms of class relations, although the class relations that the bourgeoisie exploits the proletariat does not change fundamentally, the system of co-determination by labor and capital and the system of sharing profits have enabled the relations between labor and capital of capitalism in Europe to be adjusted in a transformational way, and the economic status, political status and social status of working class are obviously enhanced, which, on one hand, cannot go without self fighting of the working class, and, on the other hand, cannot go without "collaborationism of all classes" in Western Europe and protection of a series of rights of workers placed at a central position. We find that, "At least, in Sweden and West Germany, as the typical representatives of 'collaborationism of all classes' of capitalism, they really have successfully combined protection of workers' rights with ongoing economic growth and general improvement of the living standard." (Note 4) Compared for a long time with the situation of "strong capital and weak labor" in America, the labor rights of workers in Europe are given better consideration.

In terms of income distribution, although it is still the basic economic rule for capitalism development in Europe to make a fortune and seize surplus value, social gap in Europe is being brought under control within a relatively rational scope through the policy of equalization of redistribution of income and general social welfare system, and has presented a continuously diminishing trend. After the Second World War, all countries of Western Europe and Northern Europe attached great importance to consideration of fairness of income distribution and adjustment of the gap between the rich and the poor. For example, Swedish Government adopted two major measures in order to push forward the equalization of income. Firstly, the government confined wage differentials within a rational scope; secondly, the government adopted progressive taxation of income in the policy of tax, took from the rich and gave to the poor and evened up income of all its people. After the Second World War, Germany has also been committed to diminishing the gap between the rich and the poor and realized basic social justice through secondary allocation. The government adhered to the policy of property distribution to push forward the property accumulation of common laborer families and made itself relatively equal compared with the "transatlantic rivals". (Note 5) Generally speaking, the Gini coefficient in all European countries is relatively small. For example, the Gini coefficient is 0.231 in Austria, 0.247 in Denmark, 0.25 in Sweden, 0.252 in Norway and 0.256 in Finland. Although the Gini coefficients in Britain and France are relatively high, they are no more than 0.36 and 0.32 . European countries, especially Northern European countries 
can be said to have realized "common property" to a certain extent.

In terms of superstructure, although the political party of the bourgeois still takes up a dominant position and the value concept of free democracy is still the mainstream ideology, social democracy has exerted profound influences upon Europe after the Second World War and the values of social democracy have penetrated deeply into the popular feelings. The so-called social democracy refers to the social and political ideological trend in which a political party takes office in a peaceful and legal way, "changes" or "reforms" capitalism with the reformism method and realizes the ideal target, basic demand or value orientation of socialism. After the Second World War, social democratic party of all European countries won extensive support of the social public and influences of social democracy were daily on the increase. On the whole, social democratic party had a long experience of being in office after the Second World War. For instance, the Labor Party in Britain was in power for 27 years, the French Social Party singly or jointly took the office for 23 years, the German Social Democratic Party was in office for 23 years, the Swedish Social Democratic Party was in power for more than 60 years, the Social Democratic Party of Austria was in power for 30 years, the Labor Party of Norway was in power for 38 years and the Social Democratic Party of Denmark was in power for 38 years. Although these social democratic parties have not touched the fundamental system of capitalism, they have conducted "transformation within the system" of capitalism. For example, the British Labor Party Leader Blair made a stand against British right wing' supreme individualism "indulging capitalism", and proposed establishing a Britain "with an integration of fairness and entrepreneur spirit and social justice and economic efficiency". French Social Party Leader Francois Mitterrand vigorously carried out "Frenchy socialism" after he came into power, which effectively improved income of the underdog, strengthened social welfare, gradually diminished social injustice phenomena and limited the gap between the rich and the poor. Since the Swedish Social Democratic Party came into power, it has enabled the 8.8 million of public to achieve common property and equalization of income through carrying out welfare socialism, functional socialism and funds socialism. Since the social democracy has been in power for long and has gained great public support, the value idea of social democracy has also enjoyed popular support among Europeans. In all European countries, the public not only do not go against socialism, but are more willing to accept socialism factors and the values of socialism. At the end of the century, Marx occupied the top candidate for several times in election of "thinker of a thousand years" and "the great man of a thousand years", which deeply reflected that socialism thought and socialism values had exerted profound influences among European public.

\section{How far is Europe from socialism?}

Europe is really a miraculous and particular land which is not only the most distinct flag of capitalism civilization, but also an area with the most and most obvious socialism factors in the socialism camp. In face with the lots of socialism new factors in Europe after the Second World War, people can't help but making a detailed inquiry: why such changes have taken place in Europe and how these changes indicate how far Europe is from socialism?

\subsection{Reform in Europe is deeply influenced by socialism.}

Since the Twentieth Century, an interesting historical phenomenon has emerged in the human society. That is, socialism and capitalism are developed in a paralleled way in mutual opposition, mutual fights, mutual contest, mutual interaction and mutual appreciation. In the process of mutual contest of the two systems, the contemporary capitalism decision makers illiberally believe that capitalism is "superior", but they also discover the enormous achievements of socialism. Especially after the Second World War, the amazing social development speed, brilliant material wealth and ascending social spiritual outlook created by socialism countries represented by Russia and China compelled capitalism countries to carefully study socialism and borrow and absorb achievements of socialism when they suffer from great torture and torment of economic crisis and unprecedented intensified domestic class contradictions. As the birth of place of capitalism sprout, Europe has had a development history of several hundred years. It has not only created the former European capitalism brilliance in ruling the whole world, but has also undergone two global destructive attacks. After a severe test of blood and fire, Europe recalled a painful experience and became more and more mature and rational, conducted progressive reform and improvement slowly but stably in self criticism, and gradually worked out of the social development path distinguished from America after deeply reflecting all sorts of critiques of Marxism on capitalism and after realistically facing up with all kinds of achievements in eastern socialism countries. Thus, a double development trend was exhibited in contemporary capitalism represented by Europe and America.

\subsection{Gradual reform has brought staggered qualitative change to Europe.}

Without doubt, Europe nowadays is still advancing on the path of capitalism. However, we can't ignore the 
gradual reform in Europe after the Second World War and the lots of socialism new factors, since these factors symbolizes that staggered qualitative changes have taken place in capitalism in Europe, and social development of Europe has also exhibited clear-cut historical transitivity. The traditional and single European private ownership of the means of production mode at present has been broken through, and all sorts of economic patterns of socialization of capital is continuously generated and further developed. Although economic crisis still exists, "anarchy" of social production has already been overcome and has been replaced by the "social market economy" the government plans to mediate. Although the law of surplus value is still a basic economic law, the savage exploitation mode of "taking all" and "winning all" has been abandoned, the working class no longer lives a dog's life, and the system of co-determination of labor and capital, all kinds of redistribution systems and social welfare systems not only enhance the social status of the proletariat in Europe, but also put the trend of polarization of the gap between the rich and the poor in capitalism society under control within a rational scope. The original "orthodox capitalism" in Europe is being "nibbled" and "transformed" by socialism and the sign of "socialism threshold" has appeared in quite a lot of aspects, which all indicate clearly that staggered qualitative changes have taken place in the capitalism in Europe.

\subsection{Reform in Europe predicts the possibility of another kind of socialism realization means.}

Materialistic dialectics reveals that qualitative change of any object is not accomplished in an action, and the more complicated an object is, the more staggered qualitative changes and local qualitative changes its qualitative change has to undergo. In face of the gratifying changes that have already appeared in Europe, whether people can predict Europe will finally walk towards a socialism path after a stable evolution and transition? This is a virtuous will or a realistic possibility? As a matter of fact, Engels made a definite explanation earlier, "it can be assumed, in a country where the people's representative institutions concentrate all rights in their own hand and can act at will according to the constitution so long as they gain support of the majority of the people, the old society may evolve into the new society peacefully." (Note 6) In eastern countries represented by China and Russia, we walked towards the socialism path with the means of "violent revolution", which was proved by the history to be rational under the conditions at that time. However, faced up with the historical reality of world integration and economic globalization, the conditions of adaptation of violent revolution have changed essentially. In an era with the theme of peace and development, the gradual transformation in Europe actually predicts profoundly possibility of another kind of means for realization of socialism, which is the peaceful and non-explosive qualitative means said by Engels. This kind of means also proves more profoundly that "capitalism itself has brought about its own grave digger and has created new institutional factors." (Note 7) However, on the other hand, just as this is a kind of (distinguished from the explosive qualitative change of "violent revolution") "peaceful transition" and non-explosive qualitative change, it simultaneously determines that the realization of objective necessity that Europe will walk towards socialism path will be another endless historical process.

\section{References}

David Coates. (2001). Models of Capitalism. Nanjing: Jiangsu People's Publishing House.

Hu, Liansheng \& Yang, Ling. (2008). Study on the Double Development Trend of Contemporary Capitalism. Beijing: People's Publishing House.

Michel Albert. (1999). Capitalism against Capitalism. Beijing: Social Sciences Academic Press.

Sun, Li. (2005). Capitalism: Civilization Evolving in Critique. Shanghai: Academic Press.

The Complete Works of Marx \& Engels. Vol. 25.

Zhang, Shipeng. (2003). Study on Capitalism in Western Europe in Late 1990s. Beijing: China International Broadcasting Press.

\section{Notes}

Note 1. Zhang, Ximing. (2003). New American Empire. Social Sciences Academic Press, p. 300-301.

Note 2. The Complete Works of Marx \& Engels. Vol. 25, p. 498.

Note 3. The Complete Works of Marx \& Engels. Vol. 25, p. 494, p. 496.

Note 4. David Coates. (2001). Models of Capitalism. Nanjing: Jiangsu People's Publishing House, p. 277.

Note 5. Michel Albert. (1999). Capitalism against Capitalism. Beijing: Social Sciences Academic Press, p. 148.

Note 6. The Complete Works of Marx \& Engels. Vol. 22, p. 237.

Note 7. LENIN Selected Works, Vol. 3. People's Publishing House, 1995, p. 274. 


\title{
The Language Medium Policy in Malaysia:
}

\section{A Plural Society Model?}

\author{
Ales Puteh \\ Education Studies, Universiti Utara Malaysia, Malaysia \\ E-mail: alis@uum.edu.my
}

\begin{abstract}
The aim of this study is to examine the development and the implementation of language medium policy in the Malaysia Education System and it's relation to nation building. Emerson (1957) Furnival (1948) Chopra (1974) contended that Malaysian plural society was divided in almost every respect. As a plural society, nation building or national integration (Ibrahim, 1985) was considered of the utmost importance in Malaysia. Since independence, the Malaysian leadership has believed that education is critical for national integration. It is generally believed that schools inculcate the child with values and facts, which are supportive of national ideology. The language medium policy refers to the medium of instruction in schools. It considers all the functions of language (informative, regulatory, inter national, personal) but in practice it focuses on the - the informative, the regulatory and the heuristic. This reform which has allowed English to be used as a medium of instruction, with the prior approval of the Minister of Education (section 41), was designed to enable Malaysia to make the quantum leap towards an industrialized nation status and eventually into a knowledge economy. The present study focuses on the process of development and the implementation of a education language policy in Malaysia. In addition to interviews with persons directly involved in the process of education in Malaysia, the study examines a number of scholarly publications and other primary sources of information. The findings of my study show that the language medium policy did not successfully develop unity among the students. The process of integration is taking place in the schools setting but this process is rather slow and tottering. In more ways than one the existence of national-type schools may erode the serious desire to unite all ethnic groups. The implementation process of the particular policy was seen to negate the effectiveness of other policies.
\end{abstract}

Keywords: Language medium policy, Malaysia education system, Plural society model

\section{Introduction}

Emerson (1957) Furnival (1948) Chopra (1974) contended that Malaysian plural society was divided in almost every respect. As a plural society, nation building or national integration (Ibrahim, 1980) is considered of the utmost importance in Malaysia. Since independence, the Malaysian leadership has believed that education is critical for national integration. It is generally believed that schools inculcate the child with values and facts, which are supportive of national ideology.

\section{Education Policy- language medium policy}

The language medium policy refers to the medium of instruction in schools. The

language medium policy in Malaysia's educational system is as follow:

i. national school -

primary: use Malay(5393), Mandarin(1284), Tamil (526) and English as medium of instruction (Science / Maths).

Secondary: use Malay (1645) and English as medium of instruction.

Tertiary: use Malay and English as medium of instruction.

ii. private school primary: use Malay, Mandarin, Tamil, English and Arabic as medium of instruction.

Secondary: use Malay, Mandarin, English and Arabic as medium of instruction.

Tertiary: use Malay, Arabic and English as medium of instruction.

\section{Nationalism and Nationism}

The concepts nationalism and nationism in language planning and language use have been posited by Joshua Fishman (1968). He defines nationalism (sociocultural integration) as "the process of transforming from 